OLIFERCHUK V. P. ${ }^{1 凶}$, FEDOROVYCH D. V. ${ }^{2}$

${ }^{1}$ National Forestry University of Ukraine,

Ukraine, 79057, Lviv, Gen. Chuprynka str., 103, e-mail:victorijaoliferchuk@gmail.com

${ }^{2}$ Institute of Cell Biology of Nat. Acad. Sci. of Ukraine,

Ukraine, 79005, Lviv, Drahomanova str., 14/16, e-mail: fedorovych@cellbiol.lviv.ua

$凶$ victorijaoliferchuk@gmail.com , (066) 464-36-11, (098) 631-36-17

\title{
APPLICATION OF MYCORRHIZAL FUNGUS TUBER MELANOSPORUM TO STIMULATE THE GROWTH AND DEVELOPMENT OF SOYBEAN AND SPRING BARLEY
}

\begin{abstract}
Aim. To evaluate the effect of soybean and spring barley seeds treatment with haploid cells of fungus Tuber melanosporum IMB F- 100106 on the growth and development of soybean and spring barley. Methods. The study was conducted in field conditions on the experimental field of the Department of Agroecology and Biosafety IAP NANU. The level of development of the fungus was evaluated visually and by counting ectomycorrhizal threads. Morphometric and biochemical methods were used to characterize the structure of the crop. Results. The treatment of soybean and spring barley seeds with T. melanosporum promotes productive growth and increases the yield of crops. Conclusions. Plant inoculation with T. melanosporum promotes productive growth and increases the yield of soybean and barley, promotes the possibility of creating new technologies of organic and regenerative agriculture and allows preserving of the genetic stability of this fungus.
\end{abstract}

Keywords: mycorrhiza, Tuber melanosporum, crop yields, genetic stability.

The importance of mycorrhizal fungi for soil conservation, dynamics of natural ecosystems and sustainable agriculture has been recognized worldwide for more than one century of research on this phenomenon. Mycorrhizal fungi play a significant role in nature: they help plants to better absorb water and nutrients from the soil. This means that a mycorrhizal plant has a better growth and vigor. In addition, the mycorrhizal fungi enhance plants resistance to diseases and drought. Some mycorrhizal fungi produce mushrooms such as Boletus and truffles (Tuber melanosporum) which are highly valued in the market. Tuber species are ectomycorrhizal ascomycetes establishing relationships with different host trees and forming hypogeous fruiting bodies known as truffles. The first experimental proof that Tuber spp. have the capacity to establish a symbiotic association with roots of their hosts was obtained only in the late 1960s [1]. T. melanosporum Vittad., the 'black truffle', are in great demand by the food market in many countries because of their special taste and smell, resulting from a blend of hundreds of volatile compounds [2]. The high retail prices can go up to $\$ 7000$ per $\mathrm{kg}$. Research on these fungi has focused on promoting the cultivation of these fungi to meet increasing worldwide demand and to compensate for the catastrophic decline in their natural production.

T. melanosporum colonizing roots of oak and hazelnut trees is developing typical ectomycorrhizal structures close to the roots of their plant symbionts. These include holm oaks, French oaks, hazelnut, cherry and other deciduous trees. The symbiosis of holm oak saplings and black truffles has been shown to improve photosynthesis and root growth in the plant $[3,4]$. In addition, inoculation of Cistus and oak seedlings in greenhouses and nurseries with $T$. melanosporum mycelium lead to an increase in plant growth showing that the fungus is a mutualistic symbiont $[5,6]$. It has been suggested that $T$. melanosporum may act as a biotroph with an antagonistic nature in the later stages of the interaction, but this trait remains to be experimentally verified. T. melanosporum can exist in soils in several forms such as ascospores, germinating ascospores, free-living mycelium, emanating hyphae from mycorrhizas, remainders of ascocarps and ectomycorrhizas, or other forms like mitospores or conidiospores. Studies based on genetic and genomic approaches (i.e. release of the genome sequence) have helped to take a leap toward understanding the life cycle and reproductive modes of these fungi [7]. It was found that the T. melanosporum create mycorrhiza with woody species (walnut, hazelnut, fruit trees, deciduous and coniferous species of trees and bushes), as well as raspberries, currants, blueberries [8]. The successful application of inoculation of seeds and soaking root stones of saplings for the improvement of the

\footnotetext{
${ }^{\circ}$ OLIFERCHUK V. P., FEDOROVYCH D. V.
} 
growth and development of various plants, in particular oak and other plants were described [9].

Inoculation with spores is the most common method for producing seedlings colonized with truffle mycorrhizas. However, pure cultures and ectomycorrhizas of Tuber have also been used to obtain mycorrhizal plants. Mycelium-based inoculum offers many advantages, such as lower contamination risks and more reliable root colonization. A fed-batch fermentation process of T. melanosporum was developed for the efficient production of bioactive mycelia and Tuber polysaccharides [10].Truffle mycelium can be hosted by species, which form ectomycorrhizas like those of the genus Cistus [10]. It can be also hosted by orchids without forming a classical ectomycorrhizas structure [11] or hosted by herbaceous plants, which could lodge the mycelium without forming mycorrhizas. The number of T. melanosporum genotypes have been recovered in cultivated and natural truffle fields which may have different competitive effects on the other mycobionts [12]. Several other aspects of T. melanosporum biology and its interaction with different plants remain unclear, in particular factors involved in ascocarp initiation, the nature of the link between ascocarps and mycorrhizas and atmospheric nitrogen fixation. The belowground landscape for T. melanosporum is characterized by dynamic and complex relationships among fungi, plants, microbes and insects, but the multiple players in this community are not well known, including the fungal community composition [13, 14]. Here, we test the hypothesis that T. melanosporum, can develop on the roots of leguminous and cereal plants and influence their growth and development.

\section{Materials and methods}

Two species of plant: spring barley, hybride "Patricia" and soybean variety "Mercury" - were used as a research objects. For inoculation of plants we used preparation "Micovital" active ingredient of which is Tuber melanosporum IMB F-100106 strain isolated from the natural environment, namely from the fruit body of the Perigorsky truffle. The applied agent contained $7 \times 10^{9} \pm 5 \%$ of vegetative cells Tuber melanosporum VS 1223 per dmi. The effect of mycorrhization was studied in field conditions on the experimental field of the Department of Agroecology and Biosafety IAP NAN (Bilyi Rukav village, Khmelnytsky region, Vinnytsia region) - Forest-steppe of Ukraine. The area of the experimental plot was $25 \mathrm{~m}^{2}$.
The solutions of the agent acted in a range of concentrations: for the processing of soya seeds -1 $1 / t$, for the treatment of barley seeds $-0.51 / t$ for 30 minutes. Standard preparation.

MikePro PS 3, p. (247 g /ha of seed quantity) were used as a control. The intensity of the growth processes of barley was estimated at the height of the stem when the tube was emitted (Ls-1), the number of productive stems, plant density, growth vigor, and grain productivity components were determined after harvesting, among them: weight of 1000 grains, $1000 \mathrm{~W}$, protein and starch content in grain, $\%$ of grain content. The intensity of soybean growth processes was evaluated in a 3-5 leaf stage, determining the degree of formation and development of the notation apparatus. After harvesting, the number and weight of tubers, the number of beans and seeds in beans, weight of 1000 seeds, yield, oil content and protein content were determined.

\section{Results and discussion}

Pre-sowing treatment of soybean seeds with T. melanosporum positively influenced the formation and development of the plant's nodular structure and, as a result, contributed to its active functioning (Fig. 1, table 1).

The number of nodules increased by $12.4 \%$ and their weight by $14.4 \%$ compared with the values of the control variant. During the flowering phase, in which actually occurs the most active process of biological fixation of nitrogen, all the nodules were bright red in color, which is evidence of the activity of the nitrogenous system. In addition a $9.5 \%$ increase in the number of plants per $\mathrm{m}^{2}$ was noted, compared to the control variant. The indicated parameters for the test strain exceeded the parameters for the standard preparation MikePro PS 3, p. (247 g /ha of seed quantity) the number of nodules - by $7.0 \%$, the weight of nodules - by $6.2 \%$, the number of plants per $\mathrm{m}^{2}-$ by $4.5 \%$. The use of the test T. melanosporum VS 1223 fungus strain caused the improvement of the elements of the structure of soybean yield (Table 2). The application of the test preparation for pre-sowing seed treatment lead to a $15.0 \%$ increase in the number of beans per plant, the number of beans per $\mathrm{m}^{2}$ increased by $26.0 \%$, and the weight of 1,000 seeds by $4.5 \%$, compared to the control variant indexes.

In all the experiments using the T. melanosporum the obtained values were higher than in the variant with the standard product MikePro PS 3, p. The exceedance of the test agent over the standard 
product MikePro PS 3, p. was 3.1\%. An important indicator that determines the biological value of soybeans is the protein content of seeds that is characterized by unique properties, and its amino acid composition is equivalent to animal proteins and vegetable fat, which is responsible for the energy value of soy as a raw material. Characteristics of quantity and quality of soybean under the application of T. melanosporum are given in Table 3.

The application of test strain of the T. melanosporum resulted in increase of yield of soybean,

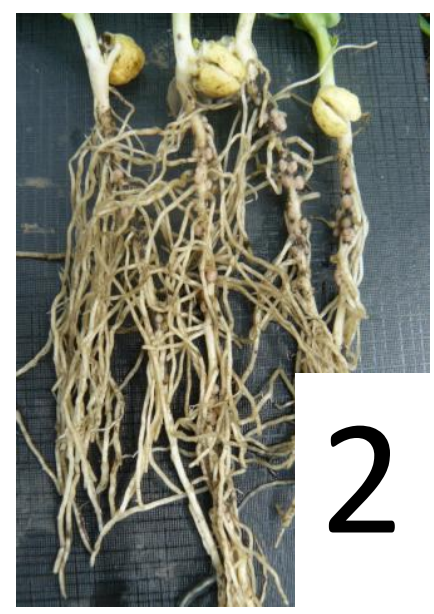

oil and protein content in seeds. The values of these indices were higher than with the standard MikePro PS 3,p. preparation.

The effectiveness of the biological action T. melanosporum was tested on the spring barley Barley seeds were treated with T. melanosporum in the $7 \times 10^{9}$ titre of cells per $\mathrm{cm}^{3}$ of the medium at the rate of $1 \mathrm{~L}$ per ton of seed. Obtained results are presented on fig. 2 and table 4.

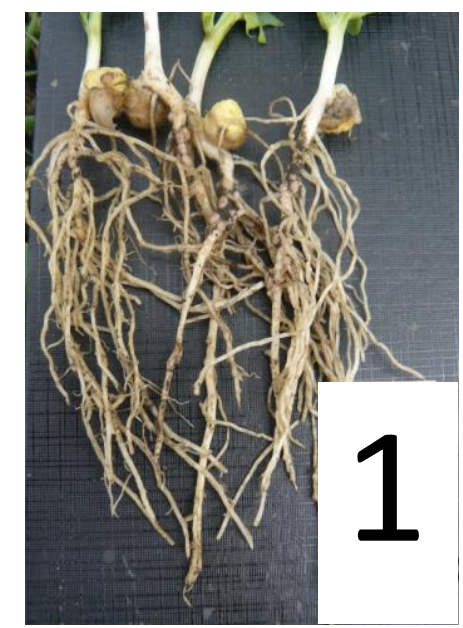

Fig. 1. The root of soybean treated with T. melanosporum (2) and without treatment (1).

Table 1. The influence of inoculation soybean seeds with T. melanosporum in the $7 \times 10^{9}$ titre of cells per $\mathrm{cm}^{3}$ of the medium on the growth and development of soybean

\begin{tabular}{|c|c|c|c|}
\hline Variant & $\begin{array}{c}\text { Number of nodules } \\
\text { pcs/plant }\end{array}$ & $\begin{array}{c}\text { Weight of nodules, } \\
\text { g/plant }\end{array}$ & $\begin{array}{c}\text { Number of plants } \\
\mathrm{pcs} / \mathrm{m}^{2}\end{array}$ \\
\hline Control (without treatment) & $29.7 \pm 0.62$ & $1.04 \pm 0.03$ & $60.9 \pm 1.08$ \\
\hline $\begin{array}{c}\text { Standard preparation } \\
\text { MikePro PS 3, p. }\end{array}$ & $31.2 \pm 0.75$ & $1.12 \pm 0.04$ & $63.8 \pm 1.1$ \\
\hline T. melanosporum & $33.4 \pm 0.51$ & $1.19 \pm 0.02$ & $66.7 \pm 1.08$ \\
\hline
\end{tabular}

Note. pcs - pieces.

Table 2. The influence of inoculation soybean seeds with T. melanosporum in the $7 \times 10^{9}$ titre of cells per $\mathrm{cm}^{3}$ of the medium on the elements of soybean yield structure

\begin{tabular}{|c|c|c|c|c|}
\hline Variant & $\begin{array}{c}\text { Number of beans, } \\
\text { pcs/plant }\end{array}$ & $\begin{array}{c}\text { Number of beans, } \\
\text { pcs } / \mathrm{m}^{2}\end{array}$ & $\begin{array}{c}\text { Number of } \\
\text { seeds, } \\
\text { pcs/bean }\end{array}$ & $\begin{array}{c}\text { Weight of } \\
1,000 \text { seeds, } g\end{array}$ \\
\hline $\begin{array}{c}\text { Control (without treat- } \\
\text { ment) }\end{array}$ & $41.2 \pm 1.7$ & $2,509.1 \pm 105.7$ & $3.0 \pm 0.04$ & $232.1 \pm 1.5$ \\
\hline $\begin{array}{c}\text { Standard preparation } \\
\text { MikePro PS 3, p. }\end{array}$ & $44.7 \pm 1.4$ & $2,851.9 \pm 106.2$ & $3.0 \pm 0.05$ & $239.4 \pm 1.1$ \\
\hline T. melanosporum & $47.4 \pm 1.4$ & $3,161.6 \pm 107.8$ & $3.0 \pm 0.03$ & $242.6 \pm 1.1$ \\
\hline
\end{tabular}


Oliferchuk V.P., Fedorovych D.V.

Table 3. The influence of inoculation soybean seeds with T. melanosporum in the $7 \times 10^{9}$ titre of cells per $\mathrm{cm}^{3}$ of the medium on yield and quality of soybean

\begin{tabular}{|c|c|c|c|c|}
\hline Variant & $\begin{array}{c}\text { Yield, } \\
\text { ton/ha }\end{array}$ & $\begin{array}{c}\text { Increase, \% of } \\
\text { control }\end{array}$ & $\begin{array}{c}\text { Oil con- } \\
\text { tent, } \%\end{array}$ & $\begin{array}{c}\text { Protein } \\
\text { content, } \%\end{array}$ \\
\hline Control (without treatment) & $2.64 \pm 0.12$ & - & $21.5 \pm 0.7$ & $38.6 \pm 0.7$ \\
\hline MikePro PS 3, p. & $2.92 \pm 0.15$ & $10.6 \pm 0.05$ & $22.1 \pm 0.6$ & $39.9 \pm 0.6$ \\
\hline T. melanosporum & $3.01 \pm 0.10$ & $14.0 \pm 0.02$ & $23.2 \pm 0.9$ & $41.5 \pm 0.7$ \\
\hline
\end{tabular}

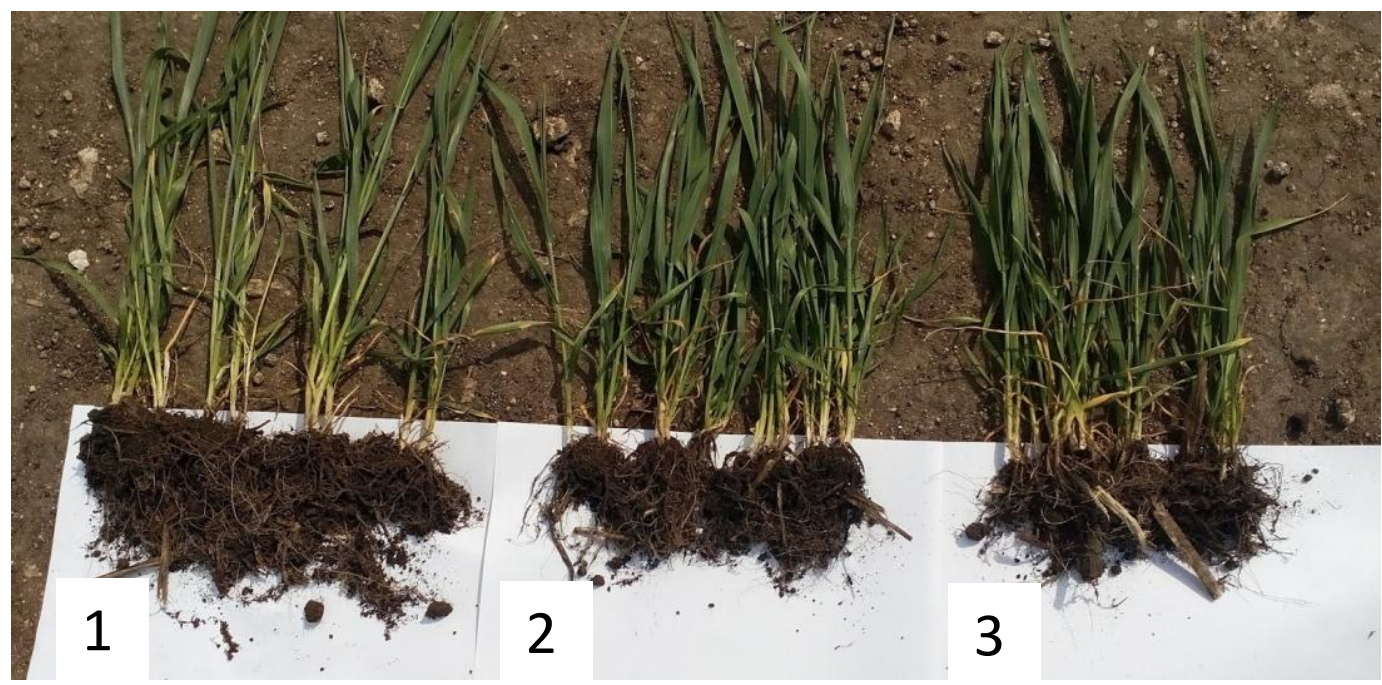

Fig. 2. The root of spring barley treated with T. melanosporum (1), MikePro PS 3, p (2) and without treatment (3).

Table 4. Influence of inoculation barley seeds with T. melanosporum on the growth and development of spring barley

\begin{tabular}{|c|c|c|c|c|c|}
\hline \multirow{2}{*}{ Variant } & \multicolumn{2}{|c|}{ Number of stems, pcs $/ \mathrm{m}^{2}$} & \multirow{2}{*}{$\begin{array}{l}\text { Height of } \\
\text { plants, see }\end{array}$} & \multirow{2}{*}{$\begin{array}{l}\text { Plant density, } \\
\text { psc } / \mathrm{m}^{2}\end{array}$} & \multirow{2}{*}{$\begin{array}{l}\text { Growth } \\
\text { force, } \%\end{array}$} \\
\hline & of all & Productive & & & \\
\hline $\begin{array}{c}\text { Control } \\
\text { (without treatment) }\end{array}$ & $560.5 \pm 6.4$ & $526.3 \pm 3.1$ & $62.5 \pm 1.8$ & $365.8 \pm 1.3$ & 77.2 \\
\hline $\begin{array}{l}\text { Standard preparation } \\
\text { MikePro PS 3, p. }\end{array}$ & $589.7 \pm 6.1$ & $569.4 \pm 2.5$ & $67.3 \pm 1.7$ & $391.3 \pm 1.2$ & 85.6 \\
\hline T. melanosporum & $601.4 \pm 5.8$ & $588.7 \pm 2.7$ & $71.8 \pm 1.6$ & $408.7 \pm 1.5$ & 89.5 \\
\hline
\end{tabular}

Notes: pcs - pieces; see - centimeters.

The use of the test agent showed positive results regarding the growth and development of spring barley (table 4). The morphometric indices of cultivated plants increased: plant height - by $14.9 \%$, density - by $11.7 \%$, growth rate - by $12.3 \%$, compared to the control variant. Also, the total number of stems per $1 \mathrm{~m}^{2}$ was increased by $7.3 \%$, and the number of productive stems per $1 \mathrm{~m}^{2}$ by $11.8 \%$, relative to control.

Growth characteristics of spring barley increased with application of the study agent also in comparison with the reference product MikePro PS 3, p. (247 g per hectare of seed rate): the total number of stems per $1 \mathrm{~m}^{2}$ increased by $2.0 \%$, the number of productive stems increased by $3.4 \%$, plant height - by $6.7 \%$, plant density - by $4.4 \%$, growth rate - by $3.9 \%$, which is evidence of the effectiveness of T. melanosporum and justifies the feasibility of its use for pre-sowing treatment of spring barley seeds.

Important indicators of grain crops are yield and quality of grain. The treatment of barley seeds by $T$. melanosporum positively influenced the yield and quality characteristics of the grain (Table.5). As a result of pre-seed treatment, the yield of barley grain increased by $13.2 \%$, compared with the control variant and by $4.7 \%$, compared to the reference product. The weights of 1000 grains increased by $9.1 \%$ and $3.1 \%$, respectively. 
Application of mycorrhizal fungus Tuber melanosporum to stimulate the growth and development of soybean and spring barley

Table 5. Yield and quality of barley grain treated with $T$. melanosporum

\begin{tabular}{|c|c|c|c|c|c|c|}
\hline \multirow{2}{*}{ Variant } & \multirow{2}{*}{$\begin{array}{l}\text { Yield, } \\
\text { c/ha }\end{array}$} & \multirow{2}{*}{$\begin{array}{c}\text { Increase, } \\
\%\end{array}$} & \multirow{2}{*}{$\begin{array}{l}\text { Weiglt of } \\
1000 \\
\text { seeds, } g\end{array}$} & \multicolumn{2}{|c|}{ Contents \% } & \multirow{2}{*}{$\begin{array}{c}\text { Filamentality } \\
\text { of grain }\end{array}$} \\
\hline & & & & Protein & Starch & \\
\hline $\begin{array}{l}\text { Control (without } \\
\text { treatment) }\end{array}$ & $53.1 \pm 0.5$ & - & $39.6 \pm 0.1$ & $10.2 \pm 01$ & $58.6 \pm 01$ & $9.6 \pm 0.2$ \\
\hline $\begin{array}{c}\text { Standard } \\
\text { preparation } \\
\text { MikePro PS 3, p. }\end{array}$ & $57.4 \pm 0.1$ & $8.1 \pm 0.1$ & $41.9 \pm 0.4$ & $11.0 \pm 0.3$ & $61.2 \pm 0.1$ & $9.4 \pm 0.3$ \\
\hline T. melanosporum & $60.1 \pm 0.2$ & $13.2 \pm 0.1$ & $43.2 \pm 0.2$ & $11.7 \pm 0.1$ & $64.1 \pm 0.1$ & $9.1 \pm 0.5$ \\
\hline
\end{tabular}

Qualitative characteristics of barley grain of yarrow determine the content of its composition of starch and protein. As a result, starch content increased by $5.5 \%$, compared to the control and by $2.9 \%$ compared to the reference product. The content of protein in the grain of barley has a similar tendency to increase by $1.5 \%$ and $0.7 \%$ respectively. The straw content of grains of barley of the fresh straw of Patricia is $0.5 \%$, compared to the control variant and $0.3 \%$, compared with the reference product

\section{Conclusions}

Inoculation of soybean and spring barley with $T$. melanosporum promotes productive growth and increases the yield of crops, promotes the possibility of creating new technologies of organic and regenerative agriculture. The above observations obviously need further work to provide more definitive answers to the functional aspects of the association of $T$. melanosporum mycelium with the non-host plants. However, already at this stage, it appears clearly that direct $T$. melanosporum interactions with non-host plants do exist, and that improved knowledge on these interactions can be used to promote new technologies of organic and regenerative agriculture and allows to preserve the genetic stability of this fungi species.

\section{References}

1. Fassi B., Fontana A. Sintesi mycorrizica tra Pinus strobus e Tuber maculatum - I. Mycorrize e sviluppo dei semenzali nel secondo anno. Allionia. 1967. Vol. 13. P. 177-186.

2. Gioacchini A.M., Menotta M., Bertini L., Rossi I., Zeppa S., Zambonelli A., Piccoli G., Stocchi V. Solid-phase microextraction gas chromatography/mass spectrometry: a new method for species identification of truffles. Rapid Communications in Mass Spectrometry. 2005. Vol. 19. P. 2365-2370.

3. Nardinia A., Salleo S., Tyree M.T., Vertovec M. Influence of the ectomycorrhizas formed by Tuber melanosporum Vitt. on hydraulic conductance and water relations of Quercus ilex L. seedlings. Annals of Forest Science. 2000. Vol. 57. P. $305-312$. doi: 10.1051/forest:2000121.

4. Olivera A., Bonet J.A., Palacio L., Liu B., Colinas C. Weed control modifies Tuber melanosporum mycelial expansion in young oak plantations. Annals of Forest Science. 2014. Vol. 71. P. 495-504. doi: 10.1007/s13595-014-0360-x.

5. Wenkart S., Roth-Bejerano N., Mills D., Kagan-Zur V., Mycorrhizal association between Tuber melanosporum mycelia and transformed roots of Cistus incanus. Plant Cell Rep. 2001. Vol. 20. P. 369-373.

6. Pinkas Y., Maimon M., Shabi E., Elisha S., Shmulewich Y., Freeman S. Inoculation, isolation and identification of Tuber melanosporum from old and new oak hosts in Israel. Mycol. Res. 2000. Vol. 104. P. 472-477.

7. Tacon F., Rubini A., Murat C., Riccioni C., Robin C., Belfiori B., Zeller B., De la Varga H., Akroume E., Deveau A., Martin F., Paolocci F. Certainties and uncertainties about the life cycle of the Pйrigord black truffle (Tuber melanosporum Vittad). Annals of Forest Science. 2016. Vol. 73. P.105-117. doi: 10.1007/s13595-015-0461-1.

8. Sally E., Smith F.A.A, David Read F.R.S. Mycorrhizas in agriculture, horticulture and forestry, in Mycorrhizal Symbiosis (Third Edition). 2008. 767 p.

9. Solti Б., Tamasky1G., Lenk S., Barycsi A., Bratek Z. Detection of the vitalization effect of Tuber mycorrhiza on sessile oak by the recently-innovated FMM chlorophyll fluorometer. Acta Biologica Szegediensis. 2011. Vol. 55. P. 147-149.

10. Liu Q.N., Liu R.S., Wang Y.H., Mi Z.Y., Li D.S., Zhong J.J., Tang Y.J. Fed-batch fermentation of Tuber melanosporum for the hyperproduction of mycelia and bioactive Tuber polysaccharides. Bioresour Technol. 2009. 100 (14). P. 3644-3649.

11. Comandini O., Contu M., Rinaldi A.C. An overview of Cistus ectomycorrhizal fungi. Mycorrhiza . 2006. Vol. 16. P. $381-395$. doi: 10.1007/s00572-006-0047-8.

12. Selosse M.A., Martin F., Bouchard D., le Tacon F. Structure and dynamics of experimentally introduced and naturally occurring Laccaria sp. Discrete genotypes in a Douglas fir plantation. Appl. Environ. Microb. 1999. Vol. 65. P. 2006-2014. 
13. Belfiori B., Riccioni C., Tempesta S., Pasqualetti M., Paolocci F., Rubini A. Comparison of ectomycorrhizal communities in natural and cultivated Tuber melanosporum truffle grounds. FEMS Microbiol Ecol.2012. Vol. 81. P. 547-561. doi: 10.1111/j.1574-6941.2012.01379.

14. Liu B., Fischer C.R., Bonet J.A., Castaco C., Colinas C. Shifts in soil fungal communities in Tuber melanosporum plantations over a 20-year transition from agriculture fields to oak woodlands. Forest Systems. 2016. Vol. 25. eSC05. doi: $10.5424 / \mathrm{fs} / 2016251-08353$.

ОЛІФЕРЧУК В. П. ${ }^{1}$, ФЕДОРОВИЧ Д. В. ${ }^{2}$

${ }^{1}$ Національний лісотехнічний університет Украӥни,

Україна, 79057, м. Львів, вул. Ген. Чупринки, 103, e-mail: victorijaoliferchuk@gmail.com

${ }^{2}$ Інститут біології клітини НАН України,

Украӥна 79005, м. Львів, вул. Драгоманова, 14/16, e-mail: fedorovych@cellbiol.lviv.иа

ЗАСТОСУВАННЯ МІКОРИЗІАЛЬНОГО ГРИБА TUBER MELANOSPORUM ДЛЯ СТИМУЛЯЦІї РОСТУ І РОЗВИТКУ СОЇ ТА ЯРОГО ЯЧМЕНЮ

Mema. Оцінити вплив обробки насіння сої та ярого ячменю гаплоїдними клітинами гриба Tuber melanosporum IMB F-100106 на ріст і розвиток сої та ярого ячменю. Методи. Дослідження проводили у польових умовах на дослідному полі відділу агроекології і біобезпеки ІАП НАН України. Рівень розвитку гриба визначали візуально і кількісно шляхом підрахунку ектомікоризних ниток. Морфометричні та біохімічні методи застосовували для характеристики структури врожаю. Результати. Обробка насіння сої та ярого ячменю гаплоїдними клітинами T. melanosporum сприяє продуктивному росту і збільшує врожайність сої та ярого ячменю. Висновки. Інокуляція рослин T. melanosporum покращує ріст і підвищує врожайність сої і ячменю, сприяє можливості створення нових технологій органічного та регенеративного землеробства та дозволяє зберегти генетичну стабільність цього гриба.

Ключові слова: мікориза, Tuber melanosporum, врожайність, генетична стабільність. 